\title{
Efektifitas Strategi Pelayanan Pastoral Konseling Kepada Pasien Panti Rehabilitasi Narkoba
}

\author{
Linda Zenita Simanjuntak ${ }^{1}$, Malik Malik ${ }^{2}$, Hasahatan Hutahaean ${ }^{3 *}$ \\ ${ }^{1}$ Sekolah Tinggi Teologi Arastamar Riau, ${ }^{2}$ Sekolah Tinggi Teologi Injili Arastamar (SETIA) Jakarta, \\ ${ }^{3}$ Sekolah Tinggi Teologi Sumatera Utara \\ Email: *Hasea2014@gmail.com
}

\begin{abstract}
The number of young people who fall into the trafficking of drugs is increasing. The phenomenon of the number of prisons and detention centers inhabited by people assisted by drug cases is no longer a secret. It is not uncommon for church youth to be counted on that number so that components of the Church such as pastors, assemblies, service activists, and other elements of society deserve to give a more serious portion of attention. Because the face of the future church cannot be separated from the Church Youth today. This research departs from this fact and the services of North Sumatra STT students at the Rehabilitation Center in Medan. More than fifteen years of experience in this area is worth exploring through field research. The method used is qualitative and with 28 people who are the objects of research from the Rehabilitation Center. Data were obtained from students who actively carry out mentoring services to Rehabilitation Institutions, Rehabilitation Institution Managers, and patient families from some of the objects (patients). The results show that there are five steps; understanding the counselee, giving loving help, the role of a father, and family prayer, provides a better change despite the variety of outcomes (cures) of people who have participated in the rehabilitation program. Pastoral care and the care of family or parents add to the healing process. This has something to do with spirituality and the pattern of pastoral Christian counseling services provided. But on the other hand, the formation of habits in serving students of the Theological College (STT) needs to be pursued through pastoral counseling services with assistance to people who are addicted and follow rehabilitation programs.
\end{abstract}

Key Words: accompaniment; counseling; drugs; pastoral; young man; Rehabilitation Orphanage

\begin{abstract}
ABSTRAK: Kaum muda yang terjerumus kepada penyalahgunaan narkoba dan obat-obatan semakin bertambah. Fenomena banyaknya Lapas dan Rutan dihuni oleh warga binaan kasus narkoba bukan rahasia lagi. Tidak jarang pula pemuda gereja yang terhitung pada bilangan itu sehingga komponen Gereja seperti pendeta, majelis, aktifis pelayanan dan elemen masyarakat lainnya patut untuk memberi porsi perhatian yang lebih serius. Sebab wajah gereja masa depan tidak terlepas dari Pemuda Gereja masa kini. Penelitian ini berangkat dari fakta tersebut dan pelayanan mahasiswa STT Sumatera Utara di Panti Rehabilitasi di Medan. Pengalaman lebih lima belas tahun pada bidang ini patut untuk ditelusuri melalui penelitian lapangan. Metode yang digunakan adalah kualitatif dan dengan 28 orang yang menjadi objek penelitian dari Panti Rehabilitasi. Data diperoleh dari mahasiswa yang aktif melaksanakan pelayanan pendampingan ke Panti Rehabilitasi, Pengelolah Panti Rehabilitasi dan keluarga pasien dari sebagian objek (pasien). Hasilnya menunjukkan adanya lima langkah; memahami konseli, memberi pertolongan penuh kasih, peran Ayah, dan doa keluarga, memberikan perubahan yang lebih baik meski adanya keragaman outcome (kesembuhan) dari orang-orang yang pernah mengikuti program rehabilitasi tersebut. Pendampingan pastoral dan perhatian keluarga atau orang tua menambah daya proses penyembuhan. Hal ini ada sangkut pautnya dengan spiritualitas dan pola pelayanan pastoral konseling Kristen yang diberikan. Namun di sisi lain pembentukan kebiasaan dalam melayani bagi mahasiswa Sekolah Tinggi Teologi (STT) perlu diupayakan melalui pelayanan pastoral konseling dengan pendampingan kepada orang-orang yang kecanduan dan mengikuti program rehabilitasi.
\end{abstract}

Kata Kunci: konseling; narkoba; pastoral; pemuda; pendampingan; panti rehabilitasi

Article History: Submitted: 23 Nopember $2020 \quad$ Revised: 28 Januari $2021 \quad$ Published: 30 Januari 2021 


\section{PENDAHULUAN}

Menguraikan pada zaman sekarang, semakin banyak manusia tidak menyadari bahwa lembaga keluarga adalah lembaga tertua yang dibangun oleh Allah. Di dalamnya ada berbagai permasalahan menyangkut banyak aspek namun di dalamnya diyakini ada kekuatan tersendiri untuk menyelesaikan berbagai permasalahan. Gaol dan Stevanus (2019) meyakini bahwa peran orang tua dapat meminimalisir berbagai pelanggaran asusila di tengah masyarakat. Ketika narkoba merebak di seluruh dunia dari kota besar hingga kota kabupaten dan ke desa-desa, salah satu pemicunya karena ada permasalahan dalam keluarga.

Fakta lain yakni belum ada klaim dari satu Lembaga atau Yayasan yang menyanggupi untuk menyelesaikan persoalan nasional ini. Kecanduan narkoba pada tingkat pemuda pelajar Sekolah Menengah Atas (SMA) pun sudah sampai pada tingkat yang memprihatinkan. Herman, Wibowo dan Rahan meneliti di Donggala menemukan bahwa pelajar SMA yang terjerumus narkoba didahului dengan minuman keras dan merokok (Herman, Wibowo, \& Rahman, 2019, p. 22). Menurut penelitian tersebut Kabupaten Donggala menempati peringkat keempat se-Provinsi Sulawesi Tengah dalam penyalahgunaan narkoba. Berdasarkan penelusuran Amanda, Humaedi dan Santoso (2017, p. 340), salah satu penyebab pemuda tidak takut dalam berbagai pelanggaran hu-kum pada usia muda adalah karena dalam pengaruh narkoba. Sehingga otak tidak dapat lagi berpikir dengan baik untuk memilah mana yang boleh atau tidak menurut hukum. Di daerah yang masih kuat tradisi kesukuan atau kekerabatannya juga dapat dirusak oleh seseorang yang telah kecanduan narkoba (Amanda et al., 2017). Kekerabatan dan hubungan kekeluargaan yang terjalin tidak lagi jadi pertimbangan dalam bertindak sebab pengaruh candu narkoba dalam tubuh menuntut zat tertentu harus dimasukkan. Karena memenuhi kebutuhan candu lebih utama dari kekerabatan dan hubungan kekeluargaan.

Sedangkan penelusuran Narindrani atas banyaknya jumlah tahanan kasus narkotika di Lapas
Cipinang, diduga oleh karena lemahnya penegakkan hukum sehingga orang tidak jera. Para tahanan jus-tru masih terus menggunakan narkoba sebab pere-daran di sana 'mampu' untuk mencukupi kebutuhan pecandu, sehingga para tahanan tidak kesulitan untuk melepas dahaga narkotik karena supply tetap berjalan dengan berbagai cara (Narindrani, 2017, pp. 112-114). Tiga fakta dari sejumlah penelitian di atas seolah menjadi miniatur pada situasi nasional di Indonesia. Narkoba merusak tatanan pemikiran, karma, cara pandang kemudian merusak tatanan sosial di tengah kehidupan berbangsa dan bernegara. Jika generasi muda dirusak sekarang ini barang tentu mengancam kehidupan masa depan masyarakat bernegara.

Fakta lain di Medan tidak banyak ditemukan Rumah atau Tempat yang fokus perhatian pada pendampingan orang kecanduan narkoba. Sekitar 12 Rumah atau Tempat yang ada di Medan, Lima diantaranya dimiliki dan dikelolah oleh Gereja, sisanya dikelolah pemerintah dan lembaga swadaya masyarakat. Mahasiswa STT Sumatera Utara melalui unit pelayanan mahasiswa BMM (Badan Misi Mahasiswa) memberikan pelayanan kepada satu Panti Rehabilitasi yang ada di Medan Selayang dan satu panti di kecamatan Medan Tuntungan. Tiap minggu mahasiswa secara berkelompok-kelompok antara 7-9 orang bergantian mengunjunginya dan memberi pelayanan rohani kepada pasien Panti Rehabilitasi. Yakni ke Panti Rehabilitasi Bethesda di Kec. Medan Selayang dan Panti Rehabilitasi Matius5., di Kec. Medan Permai yang dikelolah oleh Gereja. Pendampingan ini secara kuantitas disebut juga pelayanan pendampingan pastoral secara kelompok (Gunawan, 2018, p. 91). Di mana pendampingan boleh dikerjakan oleh seorang dengan seorang, namun ada juga pendampingan dilakukan dengan berkelompok dari satu komunitas tertentu terhadap seseorang ataupun sekelompok orang.

Secara umum dan normal, tidak ada seorang pun yang ingin menjadi pecandu (drug addict). Tetapi sekali mencoba dan mengulangi dapat mengakibatkan seseorang akhirnya terjerat untuk selama- 
lamanya. Rasa ketagihan pada obat-obat tersebut sangat sulit untuk meloloskan diri dari kecanduan. Reaksi pertama dari orang tua rata-rata terkejut dan sedih ketika mendengar anaknya terlibat dalam narkoba. Penelitian Darwin, Dalimunthe dan Sulaiman (2018) di Kabupaten Karo, Sumatera Utara memberikan rujukan yang penting bahwa orang tua turut ditarik ke dalam kesulitan ekonomi karena anak terjerumus narkoba. Selain membiayai proses hukum, keluarga juga tidak jarang harus mendukung biaya proses pemulihan anak agar lepas dari ketergantungan narkoba. Karena itu penulis menduga jika ada anak kecanduan dalam suatu keluarga yang per-lu dikonseling, maka hendaknya bukan hanya anak yang terjerumus dilayani tetapi turut juga semua anggota keluarga, supaya tahu langkah-langkah yang diambil dalam penyembuhan si anak tersebut. Orang tua dan keluarga besar perlu mendapat edukasi ba-gaimana memperlakukan anak yang terjerumus penyalahgunaan narkoba. Agar tidak ada kepanikan dan crash internal, maka gereja, pegiat konseling Kristen hendaknya memberikan porsi perhatian yang memadai pada aspek ini. Sebab keterpurukan anak muda masa kini cerminan masa depan gereja. Kesalahan menangani anak muda dalam penyalahgunaan narkoba serta zat aditif psikoptropika akan menggiringnya kepada kehilangan harapan di masa depan.

Fakta di atas menjadi pendorong untuk mengkaji peran konseling kristiani bagi korban penyalahgunaan narkoba di kalangan pemuda. Sejalan dengan itu bagaimana peran orang tua untuk turut menyukseskan proses pendampingan anak yang terjerumus narkoba. Pendampingan terhadap korban penyalahgunaan narkoba menurut hemat pe-neliti memiliki kesamaan dengan esensi dari pendampingan pastoral, yakni menjaga agar umat tetap hidup dalam tradisi kristiani sesuai firman Tuhan dalam bergereja maupun bermasyarakat (Gunawan, 2018). Peneliti sendiri terlibat dalam pelayanan di Rutan Kelas I Lab Deli, kecamatan Medan Labuan dan di Lapas Kelas IIB Binjai di Sumatera Utara, juga menyaksikan warga binaan pemasyarakatan (WBP) mayoritas dari kasus narkoba. Tidak sedikit yang sejak usia 20-an tahun telah merasakan 'dam-pak hukum' hingga belasan tahun akibat kasus nar-koba. Sekitar $40 \%$ warga binaan berasal dari kasus narkoba, di mana lebih setengah diantaranya belum berusia 30 tahun. Data ini seakan terkoneksi dengan adanya keluarga yang bermasalah sosial psikologis, yakni "sebagai keluarga yang hubungan antar ang-gota keluarganya terutama antara suami-istri, orang tua dengan anak kurang serasi, sehingga tugas-tugas dan fungsi keluarga tidak dapat berjalan dengan wajar" (Simamora \& Hasugian, 2020, p. 15). Me-nurut Petugas Rutan ada WBP yang masuk Lapas kemudian terpengaruh hingga menjadi pemakai nar-koba setelah masuk Lapas, padahal kasus hukum yang menjeratnya bukan karena kasus narkoba.

Adiksi atau kecanduan biasanya diperuntukkan kepada orang-orang yang telah kecanduan obatobatan. Misalnya kecanduan terhadap ganja, heroin, ekstasi dan lain-lain. Dalam laporan Bayu menyatakan bahwa kecanduan terhadap obat bius, dapat mengubah alam bawah sadar kita. Jadi apabila seseorang memerlukan obat-obat ini, sebenarnya ada rasa sakit yang diderita yang membuatnya tidak nyaman (Hariyanto, 2018, p. 207). Ini dapat terjadi pada siapa saja pada segala usia. Dalam situasi kecanduan tingkat tinggi apa pun tidak dapat masuk dan dipahami oleh akal pikirannya, termasuk mendengarkan firman Tuhan. Kepada orang dengan kecanduan tingkat tinggi dibutuhkan kesabaran, doa selain firman Tuhan. Sebab pada tingkat ini korban dapat terganggu psikiatrik bahkan dapat memiliki kepribadian ganda untuk mengelabui keluarga atau siapa pun demi kebebasan "menikmati” narkoba. Pada le-vel ini memerlukan penanganan dengan waktu yang sangat lama (Band. Widiyanto, 2018, p. 31).

Sebagai gejala non-psyconality disorder, penyalahgunaan obat-obatan merupakan bencana manusia yang universal. Tidak ada satu bangsa pun di dunia ini yang bebas dari penyakit ini. Ini menyangkut masalah etika Kristen yang rumit. Persoalannya bukan hanya persoalan pemakai obat mana yang boleh obat mana yang terlarang, tetapi lebih 
dari itu juga persoalan tentang motivasi dan tanggung jawab dalam pemakaian obat-obatan itu.

Semakin banyak seseorang mengonsumsi narkoba sebenarnya di hati kecilnya ia merasa semakin bersalah dan semakin menjadi depresi. Ia akan mengorbankan kebutuhan kepribadiannya, hubungannya dengan teman-teman dan keluarga, pekerjaan, tabungannya, dan apa saja yang dia punya dalam upaya mendapatkan obat-obatan.

Secara umum mereka yang menyalahgunakan zat psiko aktif (termasuk narkoba dan psikotropika) dapat dibagi menjadi tiga golongan besar yaitu: Pertama, Ketergantungan primer. Ditandai dengan adanya kecemasan dan depresi yang pada umumnya terdapat pada orang dengan kepribadian yang tidak stabil. Kedua, Ketergantungan simtoma- tis. Yaitu penyalahgunaan psikoaktif sebagai salah satu gejala dari tipe kepribadian yang mendasarinya, pada umumnya terjadi pada orang dengan kepribadian psikopatik (antisosial), kriminal, dan pemakaian obat-obatan tersebut untuk kesenangan semata. Ketiga, Ketergantungan reaktif. Terutama terdapat pada remaja karena dorongan ingin tahu, pengaruh lingkungan dan tekanan teman/kelompok sebaya. Menurut Penyuluh Kristen (PK), jenis ketiga ini patut mendapat perhatian karena masa depan masih panjang dan kedua dampaknya dalam merusak masa depan bangsa sangat besar.

Perubahan-perubahan dan tanda-tanda dapat terjadi pada seseorang yang mengonsumsi narkoba sebagai berikut:

\begin{tabular}{|c|c|c|c|}
\hline Suc & Pikiran & Ucapan & Tindakan \\
\hline $\begin{array}{l}\text { 1. Perubahan penampilan } \\
\text { muka dari penuh suka cita, } \\
\text { periang, berubah menjadi } \\
\text { pendiam, pemurung, sedih. } \\
\text { 2. Normal menjadi tidak } \\
\text { normal } \\
\text { 3. Perubahan kepribadian } \\
\text { yang biasa sabar menjadi } \\
\text { tidak sabar dan tidak dapat } \\
\text { mengendalikan diri. } \\
\text { 4. Menjadi tertutup }\end{array}$ & $\begin{array}{l}\text { 1. Suka melamun } \\
\text { berkhayal } \\
\text { 2. Egois } \\
\text { 3. Biasanya sabar } \\
\text { menjadi tidak } \\
\text { terkontrol } \\
\text { 4. Emosi naik turun }\end{array}$ & $\begin{array}{l}\text { 1. Sering bersungut- } \\
\text { sungut } \\
\text { 2. Alasan setumpuk } \\
\text { 3. Kata-kata terbata- } \\
\text { bata, cadel } \\
\text { 4. Sering makan } \\
\text { permen karet } \\
\text { 5. Suka marah, ngantuk } \\
\text { tidak pada tempatnya } \\
\text { 6. Kata-kata tidak dapat } \\
\text { dipegang, dusta. }\end{array}$ & $\begin{array}{l}\text { 1. Sikap manipulasi } \\
\text { 2. Tidak konsisten suka } \\
\text { berubah-ubah } \\
\text { 3. Sering ke tempat yang } \\
\text { tidak pantas/sepi, ruang } \\
\text { kosong, WC umum } \\
\text { 4. Suka menyendiri, tidak } \\
\text { mau bergabung dengan } \\
\text { keluarga, sering } \\
\text { mencuri, menjual } \\
\text { barang. }\end{array}$ \\
\hline
\end{tabular}

Tabel 1. Perubahan Pada Pecandu Narkoba

Peneliti mencoba melihat dari sisi pastoral, dan melalui pengalaman saat melayani dalam pemulihan anak-anak narkoba. Pelayanan pastoral dalam bidang kristiani memiliki perbedaan dengan bidang lain tentunya. Perbedaannya menurut Totok terletak pada bobot perhatian keimanan dan spiritualitas selama proses pendampingan (Wiryasaputra, 2016, pp. 49-50). Jika merujuk kepada John Campbell Nelson, dalam pelayanan pastoral orang Kristen memiliki "sumber daya iman yang sangat kaya" (Nelson, 2016, p. 187) untuk menghadapi tantangan dan keanekaragamannya oleh pengaruh apa pun termasuk globalisasi. Karena itu pada bagian berikut akan dipaparkan satu usulan terhadap upaya konseling pada orang yang kecanduan narkoba, khususnya pada usia muda.

Penelitian ini diharapkan mengambil bagian bidang edukasi bagi keluarga kristiani dalam bidang pendampingan dan konseling Kristen. STT Sumatera Utara telah mengambil sedikit porsi dalam bidang konseling ini melalui pelayanan langsung kedua Panti Rehabilitasi di Medan. Institusi-institusi yang mengambil bagian dalam pelayanan ini berharap adanya kemampuan dan ketrampilan yang mumpuni 
pada mahasiswa dalam bidang konseling, (Elia \& Soeherman, 2016, p. 49) sebab ketrampilan pada bidang ini dibutuhkan pada saat menjadi guru atau pelayanan di gereja dan lembaga luar gereja setelah menyelesaikan studinya.

Memperhatikan kebutuhan penuntasan masalah penyembuhan bagi orang-orang korban penyalahgunaan narkoba, penelitian ini diyakini mampu memberi khazanah baru dari bidang pastoral konseling Kristen.

\section{METODE}

Tulisan ini berangkat dari fakta maraknya anak muda yang terjerumus penyalahgunaan narkoba. Fakta tersebut dengan mudah ditemukan di berbagai Rutan, Lapas dan Rumah Rehabilitasi Narkoba. Dengan menelusuri berbagai fakta dan gejala di lapangan maka penelitian ini akan didekati dengan penelitian kualitatif (Hamzah, 2020a, p. 21). Fakta dan data diperoleh dari salah satu Rumah Rehabilitasi yang menjadi pelayanan perkunjungan mahasiswa STT Sumatera Utara dengan kasus korban penyalahgunan narkoba yakni Panti Rehabilitasi Bethesda di Kec. Medan Selayang. Pengalaman pelayanan Unit Pelayanan BMM STT Sumatera Utara tersebut telah berlangsung selama 15 tahun. Hingga Akhir Mei 2020 jumlah pasien dirawat sejumlah 28 orang di Panti Rehabilitasi Bethesda. Adanya keterlibatan informan, performa pelayanan hingga hasil pelayanan menjadi daya tarik tersendiri bagi penelitian ini. Informasi digali dari (wawancara) 2 (dua) orang mahasiswa, satu Penyuluh Kristen, 4 (empat) orang petugas Panti Rehabilitasi. Banyak yang telah berhasil bebas dari kungkungan keteri-katan dalam waktu singkat, namun tidak sedikit yang memerlukan waktu bertahun-tahun agar bebas dari jerat narkoba. Tulisan ini akan memaparkan fakta di lapangan tentang kecanduan, kemudian me-nelusuri literatur terkait penyebab dan dampak nar-koba. Juga ditelusuri literatur konseling atau pen-dampingan bagi korban penyalagunaan narkoba de-ngan penyajian deskriptif. Data akan dianalisa secara semiotik (Hamzah, 2020b, p. 77) dan hermeneutis
(Hamzah, 2020b). Untuk mendapatkan kebaruan bentuk pendampingan dan konseling bagi korban penyalagunaan narkoba pada usia muda.

\section{HASIL DAN PEMBAHASAN}

Dari pemaparan Petugas Panti 1 (PP.1), beberapa penyebab yang dapat dipaparkan yaitu, (i) Pengaruh tekanan dari teman. (ii) Lingkungan masyarakat sekolah. (iii) Mudah diperoleh. (iv) Alat Negara lemah. Untuk butir terakhir (iv) dari pengakuan keluarga pasien (KP.1). Menurut Petugas Panti 1 (PP.1) butir (i) hingga butir (iii) mendominasi penyebab pasien terjerumus. (ii) Ingin mencoba. Mengapa orang dapat menjadi pecandu narkoba? Pertanyaan ini sangat sulit dijawab karena setiap yang kena kecanduan itu berbeda-beda. Ada bebe-rapa teori yang menyebabkan penyalahgunaan nar-koba yang mengakibatkan kecanduan dan tingkat ketergantungannya kepada narkoba semakin lama semakin tinggi (Amanda et al., 2017) (a) Dari segi keluarga. Beberapa penyebab yang dapat dipaparkan yaitu, (i) ada gap antara orang tua dan anak kurang perhatian. (ii) Keluarga yang retak. (iii) Keharmonisan dan kebahagiaan tidak tampak. (iv) Keluarga yang sibuk tidak ada waktu, dan (v) Salah satu dari anggota keluarga adalah pemakai (orang tua, kakak, dan sebagainya). (b) Dari segi pemakai. Beberapa penyebab yang dapat dipaparkan yaitu (ii) adanya perasaan rendah diri, merasa tidak pernah dihargai, dipuji diakui. (c) Dari segi lingkungan. (d) Dari segi spiritual. Jarang beribadah atau tidak pernah sama sekali, mengakibatkan nilai spiritual dan moral tidak dimiliki (Band. Saly \& Hutahaean, 2020). Dengan demikian ada saja dalih untuk membenarkan diri karena konsepsi dosa tergerus oleh kehidupan yang kian modern. Bagi mereka pergi beribadah dengan mendengar khotbah di gereja adalah bagian membatasi kebebasannya (Lukito, 2019, p. 16). Sedangkan bagian selanjutnya dari tulisan Lukito memaparkan bahwa telah sejak lama dalam dunia sains, psikologi, sosiologi, kedokteran atau ekonomi secara perlahan telah menurunkan dengan pasti hingga pada ketidakjelasan konsep tentang dosa (Lukito, 2019). Tampak 
dari pendapat Lukito bahwa penurunan deskripsi dosa juga dipengaruhi oleh kebenaran firman Tuhan yang diberitakan pada khotbah.

Para Pemuda dan remaja yang jatuh ke dalam penyalahgunaan narkoba serta obat-obat terlarang dengan melalui tingkatan sebagai berikut: Pertama rayuan (Enticement). Dunia mempunyai berbagai macam cara untuk merayu, rayuan dapat dari TV, bioskop, majalah, internet, teman dan lain-lain. Dosa mencoba membentuk kita untuk jatuh dengan mengatakan yang enak-enak. Kedua menco-ba (Experimenting) Setelah termakan oleh rayuan iblis maka orang mulai mencoba jangan sekali-kali bereksperimen dengan obat-obat terlarang, karena sekali mencoba, maka seorang tidak dapat terlepas! Jangan beri kesempatan pada iblis (Amanda et al., 2017). Ketiga menyukai (Enjoyment) Apabila seseorang sudah sampai tahap enjoy, maka ia dalam keadaan bahaya karena ia mulai menikmati saat mengonsumsi obat-obatan tersebut dan mulai menyukai. Obat-obat tersebut seperti dapat memecahkan persoalannya. Ia merasa lebih baik karena sepertinya ia lebih dapat menghadapi hidup ini. Ada persoalan sedikit yang dihadapinya maka obatlah yang dicarinya. Obat-obatan menjadi berharga baginya ia secara bertahap menjadi tergantung pada obatobat tersebut. Keempat diperbudak (Enslavement). Di dalam tahap ini obat telah menjadi sesuatu yang terpenting dalam hidupnya. Ia telah "diperbudak" dan obat menjadi "tuan" dalam hidupnya. Yang ada dalam pikirannya ialah bagaimana caranya mendapatkan obat dan mengonsumsinya.

Biasanya orang yang sudah tahap ini kehilangan penguasaan diri untuk mengontrol. Pemakainya dan ia benar-benar sudah menjadi seorang pecandu. Obat menjadi sesuatu yang terpenting dalam hidupnya. Ia akan selalu membutuhkan obatobatan hanya supaya dapat hidup normal. Kelima kematian (Death). Apabila seseorang sudah diperbudak oleh obat-obatan, organ-organ tubuh mengalami kerusakan. Kasus yang banyak dijumpai pada drug addict (pecandu) adalah penyakit TBC, Hepatitis B, C, AIDS, jantung, lever, dan gangguan jiwa
Paranoid. Alkitab mengatakan upah dosa adalah maut (Rm. 6:23).

\section{Konseling pada Kecanduan Narkoba Usia Muda}

Akar dari masalah adiksi atau kecanduan adalah sebagai masalah dosa. Adam dan Hawa memulai kisah kejatuhan dalam dosa ini ketika ada rasa ingin lebih lagi (candu) dari kenikmatan yang telah dirasakan sebelumnya. Pada Kejadian 3 Adam dan Hawa kemudian jatuh dalam dosa sehingga timbul rasa ketakutan luar biasa kepada Allah. Dampak dosa ini kemudian diturunkan sampai kepada keturunan pada era sekarang, juga hingga masa kesudahan dunia nantinya. Salah satu adalah perhambaan dan kebusukan rohani. Namun Yesus Kristus telah datang untuk membebaskan orang yang tertawan dan menolong orang untuk mengontrol diri sebagai buah Roh Kudus (Gal 5: 22-23). Orang yang sudah ketagihan obatobatan adiktif merasa dipenjarakan, ia benar-benar tertawan dan dalam perbudakan. Karena itu membutuhkan satu pendampingan oleh konselor dalam. Wiryasaputra menjelaskan dalam tataran teoritis, bahwa teologi pendampingan adalah usaha untuk menyusun suatu teori teologis, filosofis, psikologis, dan sosiologis dalam menjawab berbagai pertanyaan fundamental tentang peradaban saling mendampingi atau mutual caring dari seluruh keluarga manusia universal dan setiap komunitas, dalam hal ini termasuk setiap komunitas keagamaan (Wiryasaputra, 2019, p. 103). Dengan dasar tersebut, maka pelaku pendampingan (konselor) tidak perlu dari orang yang menerima tahbisan secara khusus dari gereja (Wiryasaputra, 2019). Seluruh komponen umat Kristus harus bergandengan tangan, tidak terkecuali jika bekerja sama dengan agama lain. Demikian sebaliknya pelayanan konseling, pastoral atau pendampingan, hendaknya tidak diberikan kepada dalam lingkup persamaan agama, suku, budaya dan yang lain (Kaban, 2016, p. $155)$.

Konselor dapat mendorong yang bersangkutan kepada suatu pengharapan dengan mengekspresikan kepedulian konselor dan pemeliharaan Allah. Ketagihan obat meresapi kehidupan pemakai, 
oleh sebab itu harus dilakukan perubahan radikal mengenai hubungan dengan perkumpulan dengan teman-temannya, keterlibatan dengan kelompok sosialnya, dan keikut sertaan aktivitas-aktivitas obatobat dan pemakaian obat-obat lainnya.

Konseli membutuhkan kegiatan agar membuat dirinya tetap memiliki kesibukan dan pikirannya bekerja dengan hal-hal yang baru (Flp.4: 8-9), secara khusus yang berkaitan dengan membangun relasi kepada Allah. Pasien/konseli perlu diingatkan yang bahwa ia harus lebih menyerahkan dirinya kepada Kristus, ketimbang dari perkumpulan dan kegiatannya yang lama. Hadirkan baginya keselamatan yang dari Kristus dan kuasa Roh Kudus. Beberapa dukungan Alkitab yang perlu ditanamkan menjadi kesadaran yang bersangkutan antara lain: 1 Korintus 6:12, Efesus 5:18, Kolose 2:15; Yohanes 3:8, Galatia 5:13; Filipi 4:4-9. Untuk kebutuhan ini penulis menyetujui bahwa gereja perlu melepaskan diri dari kepasipan (idleness) dan ketidakberfungsian (malfunction) untuk mendukung proses penyembuhan korban narkoba di kalangan usia muda. Meminjam dua istilah dari Miroslav, Adrianus Yosi menerangkan bahwa "dua problem ini merupakan salah satu wujud kekorupan gereja saat ini dikarenakan gereja sejatinya dipanggil untuk menjadi terang dan garam dunia (Mat. 5:13-16), berinteraksi dengan dunia." (Yosia, 2020, p. 92). Bila dengan sengaja abai terhadap masalah ini, gereja dapat dikatakan mengebiri cakupan tritugas panggilannya di dunia ini.

\section{Langkah-langkah Penyembuhan}

Proses pendampingan bagi korban kecanduan narkoba memerlukan banyak pihak yang bekerja secara simultan. Ada lima butir pokok perhatian dalam proses penyembuhan bagi korban kecanduan narkoba pada usia muda. Dari lima butir ini tentu peran Ayah (butir c) tidak dapat diperankan oleh mahasiswa STT Sumatera Utara terhadap pasien di Panti Rehabilitasi. Namun mahasiswa memberi arahan agar terus menjalin kontak dengan orang tua, dan terbuka ketika Ayah dan Ibu datang membesuknya. Seluruh Tim Pelayanan BMM STT Sumatera
Utara memiliki jam doa yang wajib sebelum dan setelah kembali dari Panti Rehabilitasi. Selain itu Tim Pelayanan BMM memiliki jam doa khusus dan doa doa tertentu, selain sekali sebulan doa semalam suntuk. Pentingnya doa ini seturut dengan pendapat Besly, bahwa doa dalam pastoral konseling adalah sebagai titik awal memulai percakapan dalam pelayanan konseling. Kemudian dengan doa juga merupakan keterampilan yang dimiliki dan dipraktikkan untuk diajarkan bagi konseli (Messakh, 2019, pp. 4243). Langkah-langkah yang diambil untuk proses penyembuhan akan diuraikan pada berikut:

Pertama, Memahami konseli. Biasanya orang tua maupun keluarga yang kecanduan tidak mudah mengetahui seseorang itu telah kecanduan. Dan pada umumnya anak sendirilah yang mengakui, atau yang korban kecanduan itu mengakui bahwa dia telah kecanduan, setelah ia kecapaian dalam pengembaraan kecanduannya. Jadi perlu pemahaman terhadap diri si korban oleh konselor. Penyuluh NonPNS Agama Kristen Protestan memberikan keterangan bahwa pemahaman terhadap pasien di Rumah Panti Rehabilitasi menjadi pintu masuk terhadap tahapan-tahapan pastoral dan konseling selanjutnya. Tidak banyak yang bisa memberikan waktu, tenaga dan pikiran yang sesuai dengan kebutuhan lapangan, khususnya pasien-pasien di Rumah Rehabilitasi korban narkoba. Pasien usia muda memiliki kesulitan tersendiri, berbeda dengan pasien usia lebih dewasa.

Kedua, Pertolongan dan Kasih. Bila sudah terkena Narkoba, tindakan pertama dari pihak keluarga jangan memusuhi. Pertolongan dan kasih itulah yang harus ditonjolkan supaya ia bisa melawan ketergantungan itu. Berikan motivasi bahwa ia dapat mengalahkan kecanduan itu. Bahasa tubuh mengasihi dan membenci memiliki perbedaan gesture. Dalam tulisan Patricia (2019, p. 6) dengan penelitian berbasis kekerasan pada perempuan, menyarankan agar ada integrasi Antara kata dan tubuh secara estetis-terapis, karena dapat menjadi alternatif dalam pelayanan pastoral.

Ketiga, fungsi peran ayah sangat diperlukan pada saat orang mengalami kecanduan (Darwis et al., 
2018) Untuk itu seorang konselor harus bisa sebagai pengganti ayah bagi orang kecanduan yang dikonseling. Menurut Rut Ginting, salah satu mahasiswa yang bertugas ke Panti Rehabilitasi, seringkali keluhan-keluhan pasien melebihi pengalamannya sebagai seorang mahasiswa yang jauh lebih muda usianya. Namun dalam persekutuan doa dan jadwal-jadwal perkunjungan, Rut Ginting dan kawan-kawan mempersiapkan diri dengan berbagai keadaan yang akan muncul. Bisa saja sebagai tempat curahan isi hati, menemani menangis, teman berdoa, dan tidak jarang Rut Ginting dan kawan-kawan dianggap sebagai orang tua dalam perkunjungan-perkunjungan.

Keempat, Doa keluarga. Memang sangat sulit memberi dorongan supaya berdoa pada orang yang dikonseli (Darwis et al., 2018). Tetapi keluarga harus diaja, supaya sama-sama berdoa, dia lihat dan dia rasakan, bersama mendoakan dia. Dalam buku "Mother Theresa, A Simple Path" Lucinda Vardey (1995, p. 8) menyebutkan doa dalam keluarga memberi makan dan menghidupkan jiwa. Simamora dan Hasugian juga memberi gambaran bahwa agar keluarga tetap bertahan diperlukan iman yang kuat dari masing-masing anggota keluarga. Iman adalah suatu keyakinan yang mutlak yang diajarkan oleh Yesus tanpa ada rasa keragu-raguan sedikit pun karena tanpa iman seseorang tidak dapat melihat kerajaan Allah (Simamora \& Hasugian, 2020)

Kelima, Mengampuni. Memberikan dorongan bahwa dia diampuni, sebab kebanyakan orang yang telah mengalami kecanduan tidak layak lagi dia diampuni. Bentuk pelayanan ini berupa kepedulian yang tak terhingga dalam arti menuju penyembuhan dan bebas dari kecanduan narkoba. Merasa diam- puni, dapat memberi kekuatan spiritual untuk sembuh. Bagi korban kecanduan dalam fase tertentu merasa dirinya diampuni oleh Tuhan. Keluarga, suami atau istri adalah wujud kepedulian hadirnya Allah. Hutahaean (2013) juga menyatakan yang sama yakni bahwa kepedulian yang diberikan kepada orangorang yang termarjinalkan, seperti orang-orang yang kekurangan makan-minum, para pengungsi dan orang yang sedang melewati daerah kita, kaum papa, penderita sakit dan yang sedang dirawat, warga binaan pemasyarakatan (WBP) atau yag lebih dikenal narapindana hendaknya dilakukan secara terus-menerus untuk menjadikan tatanan kehidupan masyarakat yang lebih baik bagi mereka. Upaya menghadirkan Kerajaan Allah di dunia ini, dapat dilakukan dengan perhatian yang tulus dalam segmen yang tertera tersebut. Inilah satu wujud iman kristiani. Sebab persekutuannya di dalam Yesus Kristus diharapkan tampak bagi dunia sekitarnya, bahkan kehadiran orang Kristen harus mampu memberi rasa yang khas. Kekhasan orang-orang di dalam Kristus adalah berani mempertontonkan jati dirinya kepada khalayak, dalam semua sisi kehidupan. Inilah kerinduan yang tedapat dalam Matius 25:31-46 (Hutahaean, 2013, p. 57).

\section{Dampak Strategi Pelayanan Pastoral Konseling}

Dari tabel sebelumnya didapat gambaran kondisi pecandu narkoba. Ketika dilakukan penerapan konseling pastoral di lapangan terhadap pasien di Rumah Rehabilitasi Bethesda, dari delapan belas (18) butir pada tabel, tujuh belas butir (17) sesuai dengan kondisi pasien ketika tiba di Panti Rehabilitasi.

\begin{tabular}{|c|c|c|c|c|}
\hline Fase & Suasana hati & Pikiran: & Ucapan: & Tindakan: \\
\hline 1 & $\begin{array}{l}\text { 1. Penampilan muka } \\
\text { berubah mau sedikit } \\
\text { berbicara. Sesekali } \\
\text { murung, sedih. } \\
\text { 2. Kepribadian masih } \\
\text { tidak sabar dan tidak } \\
\text { dapat }\end{array}$ & $\begin{array}{l}\text { 1. Masih suka } \\
\text { melamun } \\
\text { berkhayal. } \\
\text { 2. Masih egois. } \\
\text { 3. Kesabaran } \\
\text { sedikit } \\
\text { terkontrol. }\end{array}$ & $\begin{array}{l}\text { 1. Bersungut-sungut } \\
\text { berkurang. } \\
\text { 2. Makin banyak alasan } \\
\text { 3. Kata-kata terbata-bata } \\
\text { bertambah lancar. Sesekali } \\
\text { kelihatan cadel }\end{array}$ & $\begin{array}{l}\text { 1. Manipulasi } \\
\text { berkurang. } \\
\text { 2. Tidak konsisten suka } \\
\text { berubah-ubah. } \\
\text { 3. Sering ke tempat } \\
\text { yang tidak }\end{array}$ \\
\hline
\end{tabular}




\begin{tabular}{|l|l|l|l|l|}
\hline mengendalikan diri. & 4. Emosi & 4. Masih makan permen & pantas/sepi, ruang \\
Khususnya jika & masih naik & karet. & kosong, WC umum. \\
mengalami ancaman & turun. & 5. Marah, ngantuk tidak pada & 4. Suka menyendiri, \\
(gangguan). & & tempatnya karena tidak & ketika keluarga \\
3. Menjadi tertutup. & & lagi menerima zat addict. & datang mau \\
& & 6. Dalam berkata-kata belum & bergabung dengan \\
& & bisa dipegang. & keluarga. \\
\hline
\end{tabular}

Tabel 2. Fase Perubahan (Band. Panti Rehabilitasi di Yoga, Baca. Dilliana, 2016, pp. 349-350)

Dalam kurun waktu yang berbeda-beda, pecandu yang memperoleh pendampingan pastoral dan konseling, menurut Petugas Panti Rehabilitasi (PP.2) akan memasuki fase kedua atau disebut juga dengan masa peralihan. Satu masa yang menentukan bagi kelangsungan perawatan menuju kesembuhan yaitu bebas dari pengaruh narkoba. Fase kedua dan ketiga akan digabung dalam satu tabel seperti di bawah.

\begin{tabular}{|c|l|l|l|l|}
\hline Fase & Suasana hati & Pikiran & Ucapan & Tindakan \\
\hline 2 & 1. Periang, mudah & 1. Mengingat- & 1. Sesekali bersungut-sungut & 1. Manipulasi tinggal \\
& senyum & ingat khotbah & jika ada hal yang & sedikit \\
& 2. Lebih & atau nasihat & mengecewakan dari teman & 2. Kadang tidak \\
tenang/normal & Pengelolah & atau pihak Panti & konsisten \\
& misalnya ada & Panti & 2. Mulai tampak komitmen & 3. Selalu permisi jika \\
& teman tidak & 2. Tidak egois & 3. Bertambah lancar. Cadel & keluar ruang kompleks \\
& sabaran & 3. Ada sabar dan & tidak hilang & rehabilitasi \\
& 3. Suka mencari & bisa & 4. Sesekali makan permen & 4. Mulai rindu \\
& teman bicara & menunggu & karet. Selera dan porsi & kedatangan keluarga \\
& 4. Mudah diajak & 4. Emosi masih & makan bertambah & (besuk) \\
& ibadah & labil, bila & 5. Ada sifat baru yaitu sabar & 5. Bersedia diarahkan \\
& 5. Mulai mau & tersinggung & dan muncul humoris & untuk ambil bagian \\
& berdoa & karena ulah & 6. Dalam berkata-kata belum & dalam pelayanan \\
& 6. Tidak sulit untuk & teman & bisa dipegang. & kumpul persembahan, \\
& dinasihati & & 7. Mulai suka berjanji & membersihkan Gereja) \\
\hline 3 & Bebas dan diijinkan & Bebas dan & Bebas dan diijinkan pulang & Bebas dan diijinkan \\
& pulang setelah & diijinkan pulang & setelah setidaknya berubah & pulang setelah \\
& berubah 100\% & setelah berubah & 90\% & setidaknya berubah 90\% \\
& & 100\% & & \\
\hline
\end{tabular}

Tabel 3. Fase Perubahan

Dari data tersebut dapat dipaparkan bahwa: Pertama fase pertama pasien masih memiliki keterikatan dan dampak penggunaan narkoba. Pada tahap tersebut pelayanan pastoral konseling masih dilakukan dengan keaktifan konselor bersama Tim secara dominan. Konseli/pasien Panti Rehabilitasi belum dapat diberikan kegiatan-kegiatan yang ada dalam ke- baktian ataupun pekerjaan-pekerjaan di Panti. Kedua, pada fase pertama konselor mengalami tantangan yang sangat berat, sebab konseli dengan tingkat kecanduan yang masih besar tidak jarang meronta serta melakukan gerakan-gerakan tiba-tiba yang dapat membahayakan konselor. Menurut Petugas Panti, biasanya orang-orang yang datang melayani akan di- 
beritahu mana pasien yang masih fase 1 , fase 2 atau yang menjelang fase 3 (persiapan untuk dikembalikan ke keluarga). Kepada konselor atau petugas penyuluh yang ditugaskan agar berhati-hati. Bahkan dalam berdoa tidak disarankan dengan mata tertutup.

Ketiga, untuk pasien pada fase 2 ada beberapa perubahan yang menggembirakan meski belum pulih sepenuhnya. Pada tahap ini konselor harus lebih jeli melihat kejujuran konseli. Percakapan-percakapan yang ada antara konseli dengan konselor hendaknya diingat (atau dicatat garis besarnya) oleh konselor. Agar konselor memiliki data tentang perubahan konseli untuk didiskusikan bersama Tim. Konselor dituntut untuk memberikan waktu, pikiran, tenaga dan berbagai upaya yang lebih banyak karena keberhasilan memasuki fase 3 ditentukan pada keuletan dan daya juang konselor pada fase ini. Di saat pelayanan kebaktian, pemberitaan firman dan berdoa hendaknya terus menekankan pentingnya menggunakan waktu yang ada untuk kegiatan-kegiatan yang berarti bagi masa depan. Tidak lupa memberikan khotbah dan diskusi dengan topik pertobatan adalah momen yang diinginkan Allah (band. Yes.43:25-26; Mzm.90:12-13).

Keempat, pada fase ketiga pasien-pasien tidak mengalami perubahan yang sama. Masing-masing pasing memiliki daya juang yang berbeda untuk bisa lepas dengan sepenuhnya dari pengaruh narkoba. Daya juang konselor terus dituntut, namun daya juang dari konseli juga harus ditumbuhkan untuk bebas dari pengaruh narkoba. Dalam tahap inilah perbedaan masing-masing pasien akan tampak. Fenomena lain yang akan muncul adalah keengganan untuk meninggalkan Panti Rehabilitasi. Faktornya karena usia pasien bertambah di Panti Rehabilitasi, dalam kurun waktu itu tidak jarang juga yang memiliki keterkaitan emosional dengan suasana Panti sehingga enggan untuk kembali ke keluarga. Keterpanggilan untuk aktif melayani menjadi Petugas Panti Rehabilitasi bisa muncul dalam pikiran pasien yang melewati fase 3 dalam waktu yang sangat lama.

Pendampingan di mana di dalamnya ada mendoakan, menasihati, memberitakan firman Tuhan adalah merupakan pelayanan Kristo-centris. Karena di dalamnya merupakan kegiatan membawa orangorang korban penyalagunaan untuk bertobat, berubah dari kebiasaan dan mengupayakan spiritualitasnya kepada iman yang benar kepada Kristus Yesus. Meski tampaknya sekadar suatu pelayanan sosial, menurut hemat peneliti pendampingan atau konseling terhadap pecandu narkoba adalah satu wujud pelayanan dari menjadi garam dan terang bagi dunia. Seperti ditekankan oleh Stevanus (2018, p. 287) bahwa gereja akan diperhadapkan dengan berbagai masalah sosial, ekonomi, politik, pendidikan, kesehatan dan berbagai masalah sosial di dunia ini dalam kaitan menghadirkan syalom. Dalam frame pemahaman ini artinya apa yang dilakukan konselor atau pendamping semata untuk membawa orang kembali pada Yesus Kristus. Memang dosa telah merusak tetapi kasih Kristus melalui konselor akan 'membawa kembali orang tersebut kembali kepada Kristus' (J.F. Sagala, 2020, p. 170) dengan tuntunan yang penuh kasih. Menurut hemat peneliti ini adalah bagian dari melakukan kehendak Bapa selagi hidup, seperti teladan Yesus ketika hidup yaitu mengerjakan kehendak Bapa. Apa yang dinyatakan Benyamin perlu ditambahkan disini yakni, jika mengingat bahwa Yesus sendiri pernah berdoa dengan khusyuk pada pagi hari di taman Getsemani, sesaat sebelum diserahkan kepada serdadu yang akan menyalibkan, Yesus berdoa agar kehendak Bapa-Nya saja yang terjadi dalam diri-Nya. Hal ini sebagai bukti bahwa Yesus sendiri konsisten dengan doa (Doa Bapa Kami) yang diajarkan-Nya kepada murid-murid. Yesus sendiri memberi contoh bahwa dalam doa yang terpenting adalah mengutamakan apa yang sebenarnya Allah kehendaki (Benyamin, 2018, p. 37). Hanya dengan mengerjakan kehendak Bapa, maka seseorang berhasil memenangkan pertaruhan melawan kehendak Iblis dalam dirinya. Ini yang seringkali juga dilupakan, di mana orang cenderung berdoa supaya apa yang diinginkan itulah yang didengarkan dan dikabulkan Allah.

Teladan ini penting untuk diikuti dan dilaksanakan oleh gereja dan Sekolah Tinggi Teologi di 
Indonesia. Mengerjakan apa yang dikehendaki Bapa. Meneladani Kristus Yesus menjadi Hamba-Nya adalah, bagaimana "mengurangi bahkan meniadakan rasa dan karsa diri sendiri" demi Dia yang dilayani (Hutahaean, 2016, p. 181). Dalam konteks pendidikan Teologi di STT, pelayanan ini menolong mahasiswa untuk memahami panggilannya kepada Allah selama studi. Sehingga pada akhirnya mahasiswa memiliki habit pelayanan dan kepedulian kepada orangorang yang hilang. Pelayanan pastoral kian dibutuhkan oleh lembaga-lembaga Kristen, terlebih gereja untuk menjadi organ yang menetap guna memberikan perhatian dan pembinaan serta pendam-pingan kepada warganya/anggota lembaga tersebut (Nugroho, 2017).

\section{KESIMPULAN}

Penelitian ini telah menyajikan fakta lapangan dan literatur dari pelayanan pastoral konseling bagi orang-orang muda yang kecanduan narkoba akibat menyalahgunakannya. Dalam penelusuran fakta didapati bahwa para pecandu tersebut

\section{DAFTAR RUJUKAN}

Amanda, M. P., Humaedi, S., \& Santoso, M. B. (2017). Penyalagunaan Narkoba di Kalangan Remaja (Adolescent Substance Abuse). Prosiding Penelitian Dan Pengabdian Kepada Masyarakat, 4(1), 339-345. https://doi.org/10.24198/jppm.v4i2.14392

Benyamin, N. C. (2018). Spiritualitas Dalam Doa Bapa Kami. Jurnal Abdiel: Khazanah Pemikiran Teologi, Pendidikan Agama Kristen Dan Musik, 2(2). http://journal.sttabdiel.ac.id/JA/article/view/30.

Darwis, A., Dalimunthe, G. I., \& Riadi, S. (2018). Narkoba, Bahaya Dan Cara Mengantisipasinya. Amaliah: Jurnal Pengabdian Kepada Masyarakat, 1(1). https://doi.org/10.32696/ajpkm.v1i1.14

Dilliana, R. A. (2016). Pean Konseling Panti Rehabilitasi Dalam Menangani Pemuda Korban Narkoba dan Implikasinya Terhadap memerlukan pendampingan yang konsisten dan tulus. Fakta di lapangan melalui Panti Rehabilitasi Bethesda membuktikan dengan pelayanan anak-anak muda (juga), para pecandu dapat kembali jika dilakukan dengan sungguh-sungguh dan kebergantungan dalam doa kepada Allah. Waktu bukan dalam garis linier yang serupa bagi tiap-tiap pecandu yang sedang mengikuti rehabilitasi untuk dapat dinyatakan sembuh secara empiris dan klinis. Karena antar seorang pecandu dan pecandu lainnya meski pada level kecanduan yang sama, dalam proses sembuh dan diijinkan pulang tidak selalu sama. Ada indikator-indikator yang berbeda satu sama lain sehingga dinyatakan sembuh dan bebas pengaruh narkoba yang kemudian diijinkan meninggalkan Panti Rehabilitasi. Dengan demikian jadwal kembali ke masyarakat juga berbeda. Salah satu jawaban dari misteri ini adalah pelayanan holistik dari perspektif pastoral konseling Kristen yang signifikan. Kompetensi personal dan sarana Panti Rehabilitasi dan pola pastoral konseling Kristen terhadap yang kecanduan narkoba perlu berjalan simultan, bukan parsial.

Ketahanan Pibadi (Studi pada Panti Sosial Pamardi Putra, Sleman, Daerah Istimewa Yogyakarta). Jurnal Ketahanan Nasional, 22(3), 334-353. https://doi.org/10.22146/jkn.16355

Elia, H., \& Soeherman, S. (2016). Rancangan Kurikulum Konseling Yang Menjawab Tantangan Zaman. In K. A. Kaunang \& L. E. Simbolon (Eds.), Pelayanan Pastoral Pada Masa Transisi Masyarakat (pp. 47-52). Malang: Persetia dan I3 Batu Malang.

Gunawan, W. (2018). Pastoral Konseling: Deskripsi Umum Dalam Teori dan Praktik. Abdiel, 2(1), 85-104. https://doi.org/10.37368/ja.v2i1.63

Hamzah, A. (2020a). Metode Penelitian Fenomenologi. Malang: Literasi Nusantara. Hamzah, A. (2020b). Metode Penelitian Kepustakaan (Revisi). Malang: Literasi Nusantara. 
Hariyanto, B. P. (2018). Pencegahan Dan Pemberantasan Peredaran Narkoba Di Indonesia. Pencegahan Dan Pemberantasan Peredaran Narkoba Di Indonesia, 1(1), 201210.

Herman, H., Wibowo, A., \& Rahman, N. (2019). Perilaku Penyalahgunaan Narkoba Di Kalangan Siswa Sekolah Menengah Atas Negeri 1 Banawa Kabupaten Donggala. MPPKI (Media Publikasi Promosi Kesehatan Indonesia): The Indonesian Journal of Health Promotion, 2(1), 21-29. https://doi.org/10.31934/mppki.v2i1.524

Hutahaean, H. (2013). Visi Yesus Bagi Umatnya (Matius 25:31-46). Didaskein, 1(2), 49-60.

Hutahaean, H. (2016). Memahami 'Menjadi Saksi' Tafsir Struktur Yesaya 44:1-8. In S. R. Paparang (Ed.), Menabur Kasih Menuai Jiwa (pp. 171-182). Jakarta: Departemen Literatur dan Media Arastamar (Delima).

J.F. Sagala, L. D. (2020). Tugas Pedagogis Gembala Dalam Menyiapkan Warga Gereja Menghadapi Perubahan Sosial. Evangelikal: Jurnal Teologi Injili Dan Pembinaan Warga Jemaat, $\quad 4(2), \quad$ 167-174. https://doi.org/10.46445/ejti.v4i2.253

Kaban, K. (2016). Pelayanan Pastoral Gereja Batak Karo Protestan (GBKP). In K. A. Kaunang \& E. L. Simbolon (Eds.), Pelayanan Pastoral Pada Masa Transisi Masyarakat (pp. 151155). Malang: Persetia dan I3 Batu Malang.

Lukito, D. L. (2019). Pudarnya Konsep Dosa Dalam Dunia Kekinian. Malang: Literatur SAAT.

Lumban Gaol, S. M. M., \& Stevanus, K. (2019). Pendidikan Seks Pada Remaja. FIDEI: Jurnal Teologi Sistematika Dan Praktika, 2(2), 325-343. https://doi.org/10.34081/fidei.v2i2.76

Messakh, B. JT. (2019). Dimensi Pastoral Dalam Doa: Menemukenali Praktik Doa Yang Bertanggungjawab Dalam Pelayanan Pendampingan Dan Konseling Pastoral. Jurnal Abdiel: Khazanah Pemikiran Teologi,
Pendidikan Agama Kristen Dan Musik, 3(2), 33-46. http://journal.sttabdiel.ac.id/JA/article/view/95.

Narindrani, F. (2017). Sistem Hukum Pencegahan Peredaran Narkotika di Lembaga Pemasyarakatan (Studi Kasus di Lembaga Pemasyarakatan Cipinang). Jurnal Rechts Vinding: Media Pembinaan Hukum Nasional, 6(1), 111-124.

Nelson, J. C. (2016). Relevansi Pelayanan Konseling Pastoral Pada Masa Kini di Indonesia. In K.

A. Kaunang \& L. E. Simbolon (Eds.), Pelayanan Pastoral Pada Masa Transisi Masyarakat (pp. 179-191). Malang: Persetia dan I3 Batu Malang.

Nugroho, F. J. (2017). Pendampingan Pastoral Holistik: Sebuah Usulan Konseptual Pembinaan Warga Gereja. Evangelikal: Jurnal Teologi Injili Dan Pembinaan Warga Jemaat, $\quad 1(2), \quad$ 139-154. https://doi.org/10.46445/ejti.v1i2.71

Patricia, P. (2019). Pelayanan Pastoral Yang Melibatkan Tubuh: Integrasi Antara Kata dan Tubuh. Jurnal Abdiel: Khazanah Pemikiran Teologi, Pendidikan Agama Kristen, Dan Musik Gereja, 3(2), 1-10. https://doi.org/10.37368/ja.v3i2.96

Saly, J. S., \& Hutahaean, H. (2020). Pengaruh Khotbah Dalam Ibadah Minggu Terhadap Kedewasaan Iman Jemaat Di GKSI Merauke. Visio Dei: Jurnal Teologi Kristen, 2(2), 225243.

https://doi.org/10.35909/visiodei.v2i2.165

Simamora, M. R., \& Hasugian, J. W. (2020). Penanaman Nilai-nilai Kristiani bagi Ketahanan Keluarga di Era Disrupsi. Regula Fidei, 5(1), 13-24. https://doi.org/10.33541/regula\%20fidei.v5i 1.44

Stevanus, K. (2018). Mengimplementasikan Pelayanan Yesus Dalam Konteks Misi Masa Kini Menurut Injil Sinoptik. FIDEI: Jurnal Teologi Sistematika Dan Praktika, 1(2), 
:284-298.

https://doi.org/10.34081/fidei.v1i2.21

Vardey, L. (Ed.). (1995). Mother Theresa, A Simple Path (First). America: The Random House Publishing Group.

Widiyanto, I. F. (2018). Psychiatric or Demonic Disorder? Abdiel, 2(1), 19-32. http://journal.sttabdiel.ac.id/JA/article/view/58.
Wiryasaputra, T. S. (2016). Pendampingan Pastoral Orang Sakit (I. L. M. Utama, Ed.). Yogyakarta: PT Kanisius.

Wiryasaputra, T. S. (2019). Konseling Pastoral di Era Milenial (1th ed.). Yogyakarta: Asosiasi Konselor Pastoral Indonesia.

Yosia, A. (2020). Merupa Wujud Evangelikalisme Di Indonesia: Suatu Usulan Awal. Veritas: Jurnal Teologi Dan Pelayanan, 19(1), 85-95. https://doi.org/10.36421/veritas.v19i1.339 